\title{
Relationship among Brand Image, Service Quality and Customer Satisfaction -Using China Airline as an Example
}

\author{
Feishuo Hung* \\ Department of Travel Industry Management, Far East University, Tainan, Taiwan \\ *Email: fshung@cc.feu.edu.tw
}

\begin{abstract}
Despite the fact that the aviation market has been noticeably hit by the recession, there has been a sign of increase in the ratio of tourist coming to Taiwan. Up until now, most researches of brand marketing have been focusing on the relation between brand image and customer perception or customer service. Few have been focusing on the discussion of brand image, service quality, and customer satisfaction. For every aviation company, the question of how to improve the customers' satisfaction and loyalty, and how to gain a broader customer in the existing market by various brand marketing methods, will prove to be a very important one. Thus, in this study, we discuss, in the point of view of the customers, the relation between customers' willingness to take the flight and customer satisfaction, service quality, and the brand image of the aviation company. The research methods conducted in this study include literature review and questionnaire survey, in which experienced passengers in Taiwan were taken as research subjects, while the questions in the questionnaire were designed with the help of sorting through related literatures. Questionnaires were conducted in the way of convenience sampling, and they included three aspects: the brand image of the aviation company, service quality, and customer satisfaction. 310 copies were handed out, and 265 valid copies were recovered.

The result shows that brand image, service quality, and customer satisfaction have a positive impact on brand interest and perceived value, while brand interest has a positive impact on perceived value and brand relationship quality. Brand image has an indirect effect mostly on brand relationship quality. Although the aviation companies are able to bring positive impact on its perceived value with its brand interest, the effect brought by its brand image is more direct and positive.
\end{abstract}

Keywords-brand image; service quality; customer satisfaction; China airline.

\section{INTRODUCTION}

Customers select products will be based on the higher brand awareness to purchase; aviation industry is in heaven flight carrying passengers or cargo to industries around, so feel at ease and comfortable in the air service to let passengers, so good service there is a good quality brand image and customer satisfaction. In other words, the customer will be based on brand image or the high-profile corporate companies to purchase consumption.

\section{RESEARCH DESIGN}

A. Questionnaire and Survey Analysis Methods developed operating variables

Through brainstorming and sink the whole industry, government and expert advice to determine and correct the assessment factor should be whether the brand image, service quality and customer satisfaction, impact factor, and then according to their degree of importance given 1-5 rating, using "Likert-type "scale form, as the way forward for points to 5 indicating" strongly agree ", 4 represents" agree "three represents" ordinary ", 2 represents" do not agree ", 1 represents" strongly disagree, "the difference between its high and low scores no good or bad, but the extent of reaction agree with the description of the subject. Projects are all equidistant from each issue of scale, respondents based on their professional background and relevant experience extreme option is checked pole agree not to consent. According to the proposed research framework, hereby will analyze the methods used are:. 1 (1) SWOT analysis (2) reliability analysis (3) correlation analysis number (4) single-factor analysis of variance (5) after the analysis, analysis tools to SPSS17.0 statistical analysis software packages will be analyzed questionnaires. This study used simple random sampling, during sampling in order to take over the China Airlines flight passengers for the study. In the sample matrix, each unit is called the same as the probability of the sample units. In the random sampling process, samples have been extracted will not be set back to the parent, it is assumed that the number of sampling architecture 1000 , the probability of each person is extracted 1000, while 200 and pumped from not set back the chances of the mother is left to be extracted become $1 / 800$ people.

\section{B. Reliability Analysis}

Brand Scale reliability analysis, service quality and customer satisfaction Letter Scale Letter Scale Analysis of reliability of the results of the analysis based on scale Cronbach's $\alpha$ coefficient to determine the internal consistency of the questionnaire. In the overall brand image Cronbach's $\alpha$ coefficient of 0.722 , within an acceptable range, as shown in Table 1 . The service quality and customer satisfaction overall dimensions Cronbach's $\alpha$ coefficients was 0.968 and 0.93 , reliability values were greater than 0.7 . 
TABLE I. BRAND IMAGE ANALYSIS

\begin{tabular}{|l|c|c|}
\hline \multicolumn{1}{|c|}{ Cronbach's $\alpha=0.722$} & Revised item-related & Item deletion of Cronbach's $\alpha$ \\
\hline \multicolumn{1}{|c|}{ item } & 0.505 & 0.687 \\
\hline 1. Airline operations, financial is superb & 0.404 & 0.698 \\
\hline 2. High visibility & 0.558 & 0.675 \\
\hline $\begin{array}{l}\text { 3. Ambitious goals for the future, and actively expand } \\
\text { routes }\end{array}$ & & \\
\hline $\begin{array}{l}\text { 4. The use of new aircraft, and regular maintenance } \\
\text { 5. Flight Technology trustworthy }\end{array}$ & 0.559 & 0.672 \\
\hline $\begin{array}{l}\text { 6.It offers comfortable seating, gourmet dining and } \\
\text { amenities on the plane }\end{array}$ & 0.180 & 0.666 \\
\hline $\begin{array}{l}\text { 7. Excellent staff service quality } \\
\text { 8. The company's flight voyage arrangements in place and } \\
\text { take off and land on time }\end{array}$ & 0.485 & 0.822 \\
\hline
\end{tabular}

\section{FREQUENCY TABLE}

Gender-wise, the participants consist of 122 "female" and 143 "male", which respectively take up $46.0 \%$ and $54.0 \%$ of the total samples. The difference is minimal. Age-wise, the participants consists mostly of " $21 \sim 30$ ", which counts 135 individuals and $50.9 \%$ of the total samples. It consists second-mostly of " $31 \sim 40$ ", which counts 66 individuals and $24.9 \%$ of total samples, and third-mostly of "41 50", which counts 28 individuals and $10.6 \%$ of the total samples. As shown above and on Table.2, flight passengers consist mostly of people at the age if

TABLE II. GENDER AND AGE FREQUENCY

\begin{tabular}{c|c|c|cc|c}
\hline \multirow{2}{*}{ Variable } & Item & $\begin{array}{c}\text { Frequ } \\
\text { ency }\end{array}$ & Percent & Valid Percent & Cumulative Percent \\
\hline \multirow{4}{*}{ Gender } & Male & 122 & 46.0 & 46.0 & 46.0 \\
& Female & 143 & 54.0 & 54.0 & 100.0 \\
\cline { 2 - 6 } & Total & 265 & 100.0 & 100.0 & \\
\hline \multirow{5}{*}{ Age } & 20 & 17 & 6.4 & 6.4 & 6.4 \\
& $21-30$ & 135 & 50.9 & 50.9 & 57.4 \\
& $31-40$ & 66 & 24.9 & 24.9 & 82.3 \\
& $41-50$ & 28 & 10.6 & 10.6 & 92.8 \\
& $51-60$ & 16 & 6.0 & 6.0 & 98.9 \\
& 60 above & 3 & 1.1 & 1.1 & 100.0 \\
\hline
\end{tabular}

"21 30" and "31 40". Education-wise, it consists mostly of "college and university", which counts 177 individuals and $64.5 \%$ of total samples. It consists second-mostly of "graduate school", which counts 61 individuals and 23.0\% of the total samples, and third-mostly of "high school", which counts 31 individuals and $11.7 \%$ of the total samples. The least of which is "junior high school", which counts 2 individuals and $0.8 \%$ of total samples. As shown above, people who take China Airlines consists mostly of those with college or university education. Occupation-wise, it consists mostly of "service industry", which counts 69 individuals and $26 \%$ of the total samples. It consists second-mostly of "Military, public, and teaching personnel", which counts 68 individuals and $25.7 \%$ of total samples. It otherwise consists of "students", 57 individuals and $21.5 \%$ of the total samples; "others", 28 individuals and $10.6 \%$ of the total samples; "industry and commerce", 21 individuals and $7.9 \%$ of the total samples; "freelance", 12 individuals and $4.5 \%$ of the total samples; "homemaker", 7 individuals and $2.6 \%$ of the total samples; and the least of which, "agriculture", 3 individuals and $1.1 \%$ of the total samples only. As shown above and on Table.3, China Airlines passengers consists mostly of those in the "service industry", and slightly lesser than which are "military, public, and teaching personnel", "student", and "others", which combine to $57.8 \%$ of the total samples, while "others" mostly consists of "manufacturing".

\section{TABLE III EDUCATION AND OCCUPATION FREQUENCY}

\begin{tabular}{|c|c|c|c|c|c|}
\hline Variable & Item & Frequency & Percent & Valid Percent & $\begin{array}{c}\text { Cumulative } \\
\text { Percent }\end{array}$ \\
\hline \multirow{4}{*}{ Education } & Junior High School & 2 & .8 & .8 & 8 \\
\hline & High Schoot & 31 & 11.7 & 11.7 & 12.5 \\
\hline & College University & 171 & 64.5 & 64.5 & 77.0 \\
\hline & Graduate School & 61 & 23.0 & 23.0 & 100.0 \\
\hline \multirow{9}{*}{ Occupation } & Agriculture & 3 & 1.1 & 1.1 & 1.1 \\
\hline & Industry Commerce & 21 & 7.9 & 7.9 & 9.1 \\
\hline & Service Industry & 69 & 26.0 & 26.0 & 35.1 \\
\hline & Student & 57 & 21.5 & 21.5 & 56.6 \\
\hline & Military Publio Teac & 68 & 25.7 & 25.7 & 82.3 \\
\hline & hing Personnel & & & & \\
\hline & Housekeep & 7 & 2.6 & 2.6 & 849 \\
\hline & Freelance & 12 & 4.5 & 4.5 & 89.4 \\
\hline & Others & 28 & 10.6 & 10.6 & 100.0 \\
\hline
\end{tabular}

\section{Customer satisfaction analysis}

TABLE IV. GENDER AND CUSTOMER SATISFACTION DIFFERENCE ANALYSIS

\begin{tabular}{|c|c|c|c|c|c|}
\hline \multirow{2}{*}{ Item } & \multicolumn{2}{|c|}{$\begin{array}{l}\text { Levene's test for equality } \\
\text { of variances }\end{array}$} & \multicolumn{3}{|c|}{$\mathrm{T}$-test for equality of means } \\
\hline & $\mathrm{F}$ & Sig. & Sig. & Mean Difference & Std. Error Difference \\
\hline $\begin{array}{l}\text { I prefer this aviation } \\
\text { company when I } \\
\text { need to buy a ticket }\end{array}$ & .617. & .433 & $.041^{*}$ & 219 & .107 \\
\hline
\end{tabular}


TABLE V. BRAND IMAGE FACTOR ANALYSIS

\begin{tabular}{|l|c|c|}
\hline \multicolumn{2}{|c|}{ Item } & \multicolumn{2}{|c|}{ Component } \\
& 1 & 2 \\
\hline The aviation company arranges schedules properly & .847 & .172 \\
with no flight delay & & \\
The aviation company offers fair prices for its tickets & .763 & .070 \\
The aviation company's staff provides fine services & .668 & .320 \\
\cline { 3 - 3 } The aviation company is very well known & .072 & .838 \\
This is a large, well-financed, and top-notch aviation & .175 & .813 \\
company & & \\
The aviation company expands its air routes actively & .394 & .617 \\
and holds grand visions for its future & & \\
\hline
\end{tabular}

\section{A. Gender and Customer Satisfaction Difference Analysis}

The result of the independent t-test analysis shows no statistical significance on the two dimensions of brand image and service quality. However, on the dimension of customer satisfaction, it shows statistical significance in different gender in the item of "I prefer this aviation company when I need to buy a ticket". More males than females agree to this statement. Thus, as shown inTable. 4 , it can be concluded that men and women hold different opinions on this matter.

TABLE VI. BRAND IMAGE FACTOR DATA ANALYSIS

\begin{tabular}{|c|c|c|c|c|}
\hline Sub-Dimensions & Factors and Variables & $\begin{array}{l}\text { Factor } \\
\text { Loading }\end{array}$ & $\begin{array}{l}\text { Cumulative } \% \\
\text { of Variance } \\
\text { Explained }\end{array}$ & $\begin{array}{l}\text { K.MO Measure } \\
\text { of Sampling } \\
\text { Adequacy }\end{array}$ \\
\hline \multirow{3}{*}{ Enterprise Operation } & 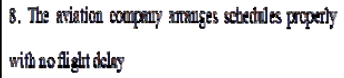 & .847 & \multirow{3}{*}{16.117} & \multirow{6}{*}{.715. } \\
\hline & 9. The aration compary offers fait prites for it tideles & .763 & & \\
\hline & 7. The a:arin company's staff provitdes fthe sentoes & .668 & & \\
\hline \multirow{3}{*}{ Enterymize Scale } & 2. The a:athon compary is is wy well horril & .838 & \multirow{3}{*}{63.545} & \\
\hline & 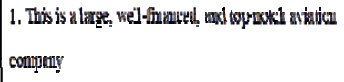 & .813 & & \\
\hline & 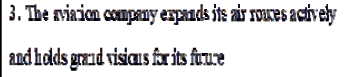 & .617 & & \\
\hline
\end{tabular}

\section{B. Brand Image Factor Analysis}

9 items were originally designed for the brand image dimension of the questionnaire. 3 items that doesn't meet the factor selection standard were later deleted through factor analysis. Table.5 shows the analysis result of qualified items in the brand image dimension. As shown inTable.6, the brand image dimension in this study is further divided into two sub-dimensions, named "Enterprise Operation" and "Enterprise Scale" respectively. The "Enterprise Operation" sub-dimension consists of three items. Its eigenvalue is 2.769 , and cumulative variance explained 46.147\%. The "Enterprise Scale" sub-dimension consists of three items: "2. The aviation company is very well known", "1.This is a large, well-defined, and top-notch aviation company", "3.The aviation Company expands its air routes actively and holds grand visions for its future". Its eigenvalue is 1.050 , and cumulative variance explained $63.645 \%$.

\section{Service Quality Factor Analysis}

In the service quality dimension, 46 items were originally designed. 20 items that did not meet the factor selection standard were later deleted through factor analysis. Table.7 shows the analysis result of qualified items in the service quality dimension. The service quality dimension in this study is further divided into four sub-dimensions, named "Related Information", "Flight Attendants' Serving Attitude", "Baggage Delivery", and "Booking Service" respectively. The "Related Information" sub-dimension consists seven items: "32.Introductions of various travel-related products are provided", "31.Information of various product promotions is provided", "44.Customized information is provided in accordance to my preference", "43.Latest news of member-exclusive discounts is provided", "33.Online purchase of travel-related products is provided", "34. Time-saving searching functionality is provided", and " 38 . Links to related traveling websites are provided". Its eigenvalue is 9.076 , and cumulative variance explained $43.219 \%$.As shown in Table.8, the "Flight Attendants' Serving Attitude" sub-dimension consists of seven items: "9. Flight attendants interact and communicate with passengers well", "8. Flight attendants offer services efficiently", "10. Flight attendants offer services in an amiable, caring, and active manner", "12.Flight attendants handle all problems properly", "11. Flight attendants understand customers' need", "27. My opinion of the company's visual presentation (hardware in the counters, decoration, uniform, vigor, etc)", and "5. Boarding announcements are accurate and clear". Its eigenvalue is 1.954, cumulative variance explained $52.521 \%$, and KMO value 0.912. The "Baggage Delivery" sub-dimension consists of four items: " 16 . The baggage claiming process is efficient", "17. The information platform for baggage delivery is superb", "15. Staff provides active assistance when checking in baggage", and " 14 . The check-in staff is kind and cautious". Its eigenvalue is 1.212 , and cumulative variance explained 58.295\%. The "Booking Service" sub-dimension consists of three items: "39. Online flight booking is available", "40. A wide variety of payment methods are available", and " 35 . An inquiry system for transaction information is available". Its eigenvalue is 1.066 , cumulative variance explained $63.373 \%$, and $\mathrm{KMO}$ value $0.912 \%$. 
TABLE VII. SERVICE QUALITY FACTOR ANALYSIS

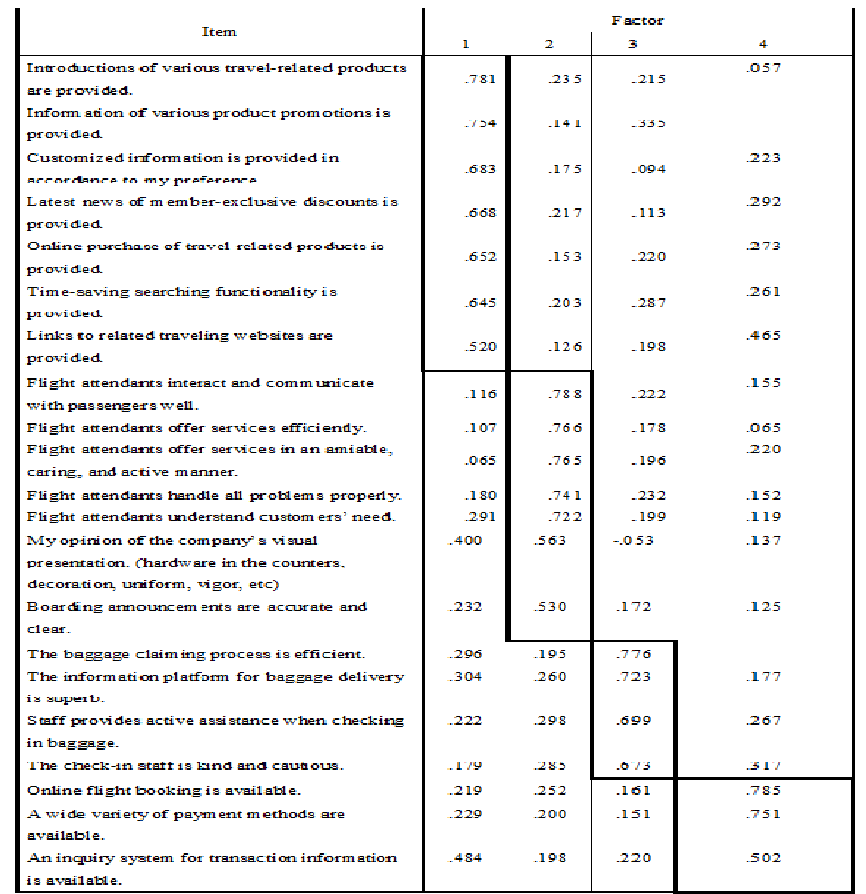

TABLE VIII. SERVICE QUALITY FACTOR DARA ANALYSIS

\begin{tabular}{|c|c|c|c|c|}
\hline $\begin{array}{l}\text { Sob-dinension } \\
s\end{array}$ & Factors and Varizbiles & $\begin{array}{l}\text { Factor } \\
\text { Louding }\end{array}$ & \begin{tabular}{|l|}
\multicolumn{2}{l|}{ Cumulative } \\
$\%$ \\
Variance \\
Explained
\end{tabular} & $\begin{array}{l}\text { KMO Measure of } \\
\text { Ssmpling Adequacy }\end{array}$ \\
\hline \multirow{7}{*}{$\begin{array}{l}\text { Related } \\
\text { Information }\end{array}$} & 32. Introductions of various travel-related products are provided. & .781 & \multirow{7}{*}{43.219} & \multirow{10}{*}{912} \\
\hline & 31. Informution of various product promotions is provided. & 754 & & \\
\hline & $\begin{array}{l}\text { 44. Customized information is provided in accordance to } \\
\text { my preference. }\end{array}$ & .683 & & \\
\hline & 43. Latest news of member-exclusive discounts is provided. & 668 & & \\
\hline & 33. Online purchase of travel-related products is provided. & 652 & & \\
\hline & 34. Time-saving searching fiunctionality is provided. & .645 & & \\
\hline & 38. Links to related traveling websites are provided. & 520 & & \\
\hline \multirow{7}{*}{ 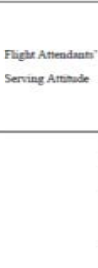 } & $\begin{array}{l}\text { 39. Flight attendants interact and commmaicate with } \\
\text { passengers well. }\end{array}$ & .788 & \multirow{3}{*}{52.521} & \\
\hline & 8. Flight attendants offer services efficiently. & .766 & & \\
\hline & $\begin{array}{l}\text { 10. Flight attendants offer services in an amiable, caring. } \\
\text { and active manger. }\end{array}$ & .765 & & \\
\hline & 12. Flight attendants handle all problems property. & .741 & & \\
\hline & 11. Flight attendants understand customers' need. & .722 & & \\
\hline & $\begin{array}{l}\text { 27. My opinion of the company's vistual presentation. } \\
\text { (hardware in the counters, decoration, uniform, vigor, etc) }\end{array}$ & .563 & & \\
\hline & 5. Boarding announcements are accurate and clear. & 530 & & \\
\hline \multirow{4}{*}{$\begin{array}{l}\text { Baggage } \\
\text { Delivery }\end{array}$} & 16. The baggage claiming process is efficient. & 776 & \multirow{4}{*}{58.295} & \\
\hline & $\begin{array}{l}\text { 17. The information platform for bagegage delivery is } \\
\text { superb. }\end{array}$ & .723 & & \\
\hline & $\begin{array}{l}\text { 15. Staff provides active assistance when checking in } \\
\text { baggage. }\end{array}$ & 699 & & \\
\hline & 14. The check-in staff is kind and cautious. & .673 & & \\
\hline \multirow{3}{*}{$\begin{array}{l}\text { Booking } \\
\text { Service }\end{array}$} & 39. Online flight booking is available. & .785 & \multirow{3}{*}{63.373} & \\
\hline & 40. A wide variety of payment methods are available. & .751 & & \\
\hline & $\begin{array}{l}\text { 35. An inquiry system for transaction information is } \\
\text { available. }\end{array}$ & .502 & & \\
\hline
\end{tabular}

TABLE IX. CUSTOMER SATISFACTIONFACTOR ANALYSIS

\begin{tabular}{|l|l|l|}
\hline \multicolumn{2}{|c|}{ Item } & \multicolumn{2}{|c|}{ Component } \\
\cline { 2 - 4 } & 1 & 2 \\
\hline I would recommend this aviation company to my colleagues and others likewise. & .80 & .202 \\
I prefer this ariation compary when I need to buy a ticket. & .763 & .279 \\
This aviation company satisfies me more than any other aviation companies. & .733 & .357 \\
I'm satisfied with both the price I paid and the tangible intangible value I & .701 & .278 \\
received. & & \\
I would buy from this aviation company and accept its service despite the & .684 & .139 \\
promotional daals from its competitors. & & \\
I wish all the other aviation companies were like this one. & .682 & .377 \\
I am very satisfied with this aviation company. & .662 & .386 \\
Interactions with this aviation company have always been pleasant. & .646 & .436 \\
Overall, I am satisfied with this aviation company's performance. & .579 & .489 \\
\hline Promises mads to the aviaticn companty were fulfilled. & .228 & .817 \\
The staff gains the trust of tte customers with good performance. & .334 & .736 \\
The ground personnel fulfilltheir service within designated time frame. & .278 & .742 \\
Jobs are done right withouta second try. & .316 & .740 \\
Staff possesses the required expertise for problem solving. & .259 & .739 \\
\hline
\end{tabular}

\section{Customer Satisfaction Factor Analysis}

In the customer satisfaction dimension, 14 questions were originally designed, all items met the factor selection standard, therefore, no item was deleted. The result of the analysis is shown in Table.9.

As shown in Table.10, the "Customer Satisfaction" dimension in this study was further divided into two sub-dimensions, named "Impressions on the Aviation Company" and "Impressions on the Staff". The "Impressions on the Aviation Company" sub-dimension consists of nine items: "8. I would recommend this aviation company to my colleagues and others likewise", "7. I prefer this aviation company when I need to buy a ticket", "4. This aviation company satisfies me more than any other aviation company", "6. I'm satisfied with both the price I paid and the tangible/intangible value I received", "9. I would buy from this aviation company and accept its service despite the promotional deals from its competitors", "3. I wish all the aviation companies were like this one", "I am very satisfied with this aviation company", "Interactions with this aviation company have always been pleasant", and "Overall, I'm satisfied with this aviation company's performance". Its eigenvalue is 7.488 , and cumulative variance explained $53.484 \%$. The "Impressions on the Staff" sub-dimension consists of five items: "12. Promises made to this aviation company were fulfilled", "13. The staff gains the trust of the customers with good performance", "11. The ground personnel fulfill their service within designated time frame", and "Jobs are done right without a second try". Its eigenvalue is 1.258, and cumulative variance explained $62.475 \%$. 
TABLE X. CUSTOMER SATISFACTION FACTOR DATA ANALYSIS

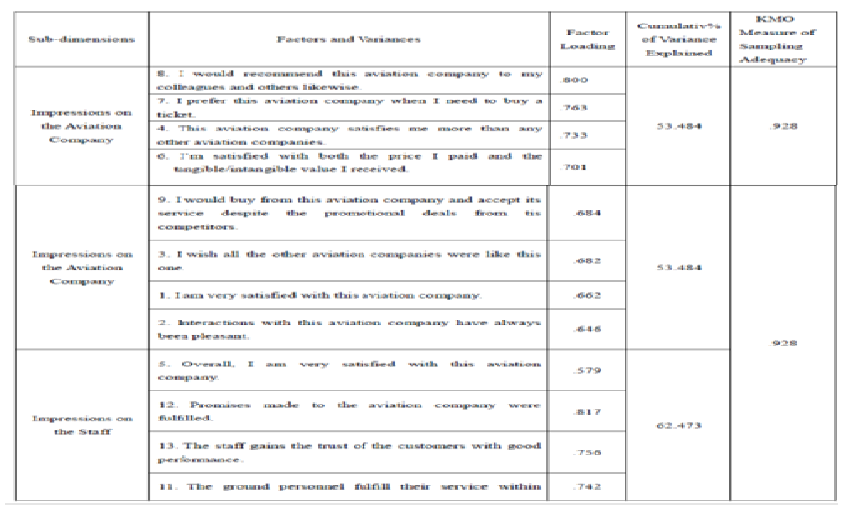

TABLE XI. BRAND IMAGE CORRELATION ANALYSIS

\begin{tabular}{|c|c|c|c|c|c|c|c|}
\hline & & $\begin{array}{l}\text { This is a larye, } \\
\text { well-inanced, } \\
\text { and top-notch } \\
\text { avialiue } \\
\text { compenty. }\end{array}$ & 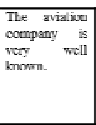 & 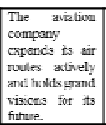 & 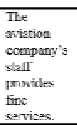 & 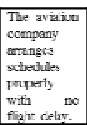 & 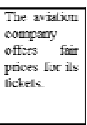 \\
\hline $\begin{array}{l}\text { This is a lange, well- } \\
\text { finsncod. and top--ioth }\end{array}$ & $\begin{array}{l}\text { Pearsum } \\
\text { Comsalobion }\end{array}$ & 1 & $.517\left({ }^{(*)}\right)$ & $.428\left({ }^{*}\right)$ & $\left..3055^{* *}\right)$ & $.323\left({ }^{*+}\right)$ & $.235\left(^{(* *)}\right.$ \\
\hline $\begin{array}{l}\text { The avietion company is } \\
\text { verry wal hornn. }\end{array}$ & $\begin{array}{l}\text { Pearsonn } \\
\text { Comraistion }\end{array}$ & $517^{\left({ }^{*}\right)}$ & 1 & $3811^{(* *)}$ & $273^{(*)}$ & $\left.260^{(*)}\right)$ & $189\left({ }^{* *}\right)$ \\
\hline 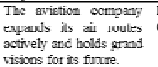 & $\begin{array}{l}\begin{array}{l}\text { Pearson } \\
\text { Curidiluu }\end{array} \\
\end{array}$ & $.128\left(^{(*)}\right)$ & $\left.3811^{(*)}\right)$ & 1 & $.131\left({ }^{(*)}\right)$ & $306^{(*)}$ & $321\left({ }^{(*)}\right)$ \\
\hline $\begin{array}{l}\text { The avialiju cunlyay's } \\
\text { staff provides fing } \\
\text { scrios. }\end{array}$ & $\begin{array}{l}\text { Preasum } \\
\text { Comrazbor }\end{array}$ & $305(*)$ & $273(* 4)$ & $.434\left({ }^{(4)}\right)$ & 1 & $5477^{(4)}$ & $255(+4)$ \\
\hline 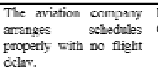 & $\begin{array}{l}\text { Preasum } \\
\text { Corrazion }\end{array}$ & $323\left(^{(*)}\right)$ & $\left.26 \mathrm{C}^{\left({ }^{*}\right)}\right)$ & $306(4+4)$ & $547(+4)$ & 1 & $500 x^{(4)}$ \\
\hline 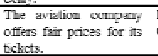 & $\begin{array}{l}\text { Pearson } \\
\text { Compation }\end{array}$ & $.2366^{(* 5)}$ & $.189\left(9^{(44)}\right)$ & $\left..321^{(* *)}\right)$ & $255($ क्क) & $\left..5000^{(8)}\right)$ & 1 \\
\hline
\end{tabular}

TABLE XII. RELATED INFORMATION CORRELATION ANALYSIS

\begin{tabular}{|c|c|c|c|c|c|c|c|c|}
\hline & & \begin{tabular}{|l|} 
Tnformati \\
on of of \\
various \\
product \\
provisulio \\
ins is \\
procidided
\end{tabular} & \begin{tabular}{|l|} 
Tnitroxhict \\
ions of \\
various \\
travel- \\
relaled \\
products \\
are \\
provided.
\end{tabular} & \begin{tabular}{|l|} 
Online \\
purchase \\
of traxel- \\
rclatcol \\
products \\
is \\
provided
\end{tabular} & 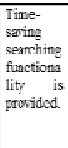 & $\begin{array}{l}\text { T.inks to } \\
\text { related } \\
\text { traveling } \\
\text { wicbsites } \\
\text { are } \\
\text { provided. }\end{array}$ & $\begin{array}{l}\text { Tatest } \\
\text { news of } \\
\text { member- } \\
\text { creclusing } \\
\text { discrumls } \\
\text { is } \\
\text { provided }\end{array}$ & 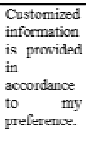 \\
\hline $\begin{array}{lr}\text { Information } & \begin{array}{r}\text { of } \\
\text { various } \\
\text { promotions }\end{array} \\
\text { provodided. } & \text { is } \\
\end{array}$ & $\begin{array}{l}\text { Persom } \\
\text { Correlation }\end{array}$ & 1 & $755^{(* * 4)}$ & $478(* *)$ & $522(* *)$ & $450^{(* *)}$ & $508\left({ }^{* * 7}\right)$ & $404\left({ }^{* *}\right)$ \\
\hline $\begin{array}{l}\text { Introductions } \\
\text { various travel-relatei } \\
\text { products are provided. }\end{array}$ & $\begin{array}{l}\text { Persom } \\
\text { Correlation }\end{array}$ & $.755(* *)$ & 1 & $.548(* *)$ & $510\left(0^{* *}\right)$ & $.466(* *)$ & $565(* *)$ & $.492\left({ }^{(* *)}\right.$ \\
\hline $\begin{array}{l}\text { Online purchase of } \\
\text { travel related products } \\
\text { is provided }\end{array}$ & $\begin{array}{l}\text { Persom } \\
\text { Correlation }\end{array}$ & \begin{tabular}{|l|}
$478(* *)$ \\
\end{tabular} & $548(* *)$ & 1 & $662(* *)$ & $415\left({ }^{* *}\right)$ & $491\left({ }^{* *}\right)$ & $511(* *)$ \\
\hline $\begin{array}{l}\text { lime-saring } \\
\text { searching } \\
\text { functivnality } \\
\text { provided. } \\
\text { Links to related } \\
\text { traveling wiehsites are }\end{array}$ & $\begin{array}{l}\text { Person } \\
\text { Correlation } \\
\text { Person } \\
\text { Correlation }\end{array}$ & $.522\left({ }^{(8)}\right)$ & $510^{(8 *)}$ & $.6622^{(8 x)}$ & $.492(* *)$ & $492\left({ }^{(* x)}\right.$ & $5022^{(88)}$ & $.489(* \star)$ \\
\hline $\begin{array}{l}\text { Lalest news of } \\
\text { member-crclusine } \\
\text { discounts is provided }\end{array}$ & $\begin{array}{l}\text { Pearvoum } \\
\text { Corrclation }\end{array}$ & \begin{tabular}{|l|}
$.508(* *)$ \\
\end{tabular} & $.565(* *)$ & $.491\left(^{(* *)}\right.$ & $502(* *)$ & $.443(* *)$ & 1 & $.563(* *)$ \\
\hline $\begin{array}{l}\begin{array}{l}\text { Customized } \\
\text { information } \\
\text { pruvided } \\
\text { accordanoc } \\
\text { preference. }\end{array} \text { to in } \\
\text { ing } \\
\end{array}$ & $\begin{array}{l}\text { Perssom } \\
\text { Correlation }\end{array}$ & $\mid 404\left({ }^{* *}\right)$ & $492(* *)$ & $511(* *)$ & $489(* *)$ & $514\left(\right.$ (**) $^{2}$ & $563\left({ }^{* *}\right)$ & 1 \\
\hline & Siz_. (2-lailed) & .000 & .000 & .000 & .000 & .000 & .000 & \\
\hline & & 265 & 265 & 265 & 265 & 265 & 265 & 265 \\
\hline
\end{tabular}

\section{E. Brand Image and Service Quality Correlation Analysis}

As shown inTable.11, the result of the brand image dimension's correlation analysis shows evident significance, which means that the following items "This is a large, well-financed, and top-notch aviation company", "The aviation company is very well known", "The aviation company expands its air routes actively and holds grand visions for its future", The aviation company's staff provides fine services", "The aviation company arranges schedules properly with no flight delay", and "The aviation company offers fair prices for its tickets" have an impact on China Airline's brand image. As shown in Table.12, the service quality correlation analysis shows evident significance for all related information. The two items "Introductions of various travel-related products are provided", and "Information of various product promotions is provided" shows high significance in the correlation analysis, which means that the two items share more relevance between each other than other items in the related information analysis. Table.13shows evident significance in all the flight attendants' attitude correlation analysis. Two particular items "Flight attendants offer services in an amiable, caring, and active manner", and "Flight attendants interact and communicate with passengers well" show high significance in the correlation analysis, which means that the two items share more relevance than other items in the flight attendants' attitude analysis. Table.14 shows evident significance in all the baggage delivery correlation analysis. Two particular items "The information platform for baggage delivery is superb", and "The baggage claiming process is efficient" show high significance in the correlation analysis, which means that the two items share more relevance than other items in the baggage delivery correlation analysis. Table.15shows evident significance in all the booking service correlation analysis. Two particular items "A wide variety of payment methods are available", and "Online flight booking is available" show high significance in the correlation analysis, which means that the two items share more relevance than other items in the booking service correlation analysis. As shown in Table.16, the combined correlation analysis of the service quality sub-dimension shows evident significance, with particularly high significance on "Related Information", "Baggage Delivery", and "Booking Service". It can be concluded that some information about baggage delivery and booking service could be previously obtained on related information, and related information is correlated with baggage delivery and booking service, which poses an impact to service quality.

TABLE XIII. RELATED INFORMATION CORRELATION ANALYSIS

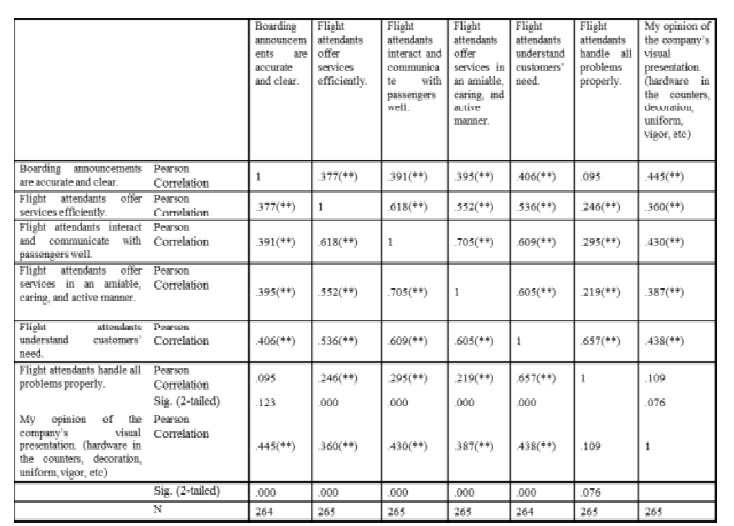


TABLE XIV. BAGGAGE DELIVERY CORRELATION ANALYSIS

\begin{tabular}{|c|c|c|c|c|c|}
\hline & & $\begin{array}{l}\text { The check-in } \\
\text { slafl is kind } \\
\text { and cautious. }\end{array}$ & $\begin{array}{l}\text { Staff provides } \\
\text { active assislance } \\
\text { when checking } \\
\text { in baggage. }\end{array}$ & $\begin{array}{l}\text { The baggage } \\
\text { claining } \\
\text { procass is } \\
\text { eficient. }\end{array}$ & \begin{tabular}{|lrl} 
An & inquiry \\
syylem & for \\
transection \\
information is \\
available.
\end{tabular} \\
\hline $\begin{array}{l}\text { The check-in staff is ind and } \\
\text { cautious. }\end{array}$ & $\begin{array}{l}\text { Pearson } \\
\text { Conclation } \\
\text { Sis, (2-tailec) }\end{array}$ & 1 & $\begin{array}{c}.681\left(\text { (*) }^{2}\right) \\
.000\end{array}$ & $\begin{array}{c}.504\left(^{(*)}\right) \\
.000\end{array}$ & $\begin{array}{l}\left..5366^{* \pm}\right) \\
.000\end{array}$ \\
\hline $\begin{array}{l}\text { Staff provides activc assisttance whin } \\
\text { chacking in baggage. }\end{array}$ & $\begin{array}{l}\text { Pcarson } \\
\text { Comelation } \\
\text { Siz (2-taileci) }\end{array}$ & $\begin{array}{c}.681(\$ *) \\
.000\end{array}$ & 1 & $\begin{array}{c}\left..5200^{(*)}\right) \\
.000\end{array}$ & $\begin{array}{l}.587+ \pm \pm 2) \\
.000\end{array}$ \\
\hline $\begin{array}{l}\text { The baggage claiming process is } \\
\text { efficient. }\end{array}$ & $\begin{array}{l}\text { Pearson } \\
\text { Correlation } \\
\text { Siz (2-tailec) }\end{array}$ & $\begin{array}{c}.504(* *) \\
.000\end{array}$ & $\begin{array}{l}\left..52(* *)^{*}\right) \\
.000\end{array}$ & 1 & $\begin{array}{l}.650(* 7) \\
.000\end{array}$ \\
\hline $\begin{array}{l}\text { An inquiry system for tansaction } \\
\text { infomation is available. }\end{array}$ & $\begin{array}{l}\text { Pearson } \\
\text { Correlation }\end{array}$ & $.536\left({ }^{* *}\right)$ & $.587\left(* \frac{*}{*}\right)$ & $.690(* *)$ & 1 \\
\hline & Siয় (2-taileć) & .000 & .000 & .000 & \\
\hline & $\mathrm{N}$ & 265 & 265 & 265 & 265 \\
\hline
\end{tabular}

TABLE XV. BOOKING SERVICE CORRELATION ANALYSIS

\begin{tabular}{|c|c|c|c|c|}
\hline & & \begin{tabular}{|l|l|} 
An inquiry \\
systen for \\
transaclivin \\
information \\
is available. \\
\end{tabular} & $\begin{array}{lr}\begin{array}{l}\text { Online } \\
\text { backing }\end{array} & \text { flight } \\
\text { avilable: } & \end{array}$ & $\begin{array}{l}\text { A wide variety of } \\
\text { payment methods are } \\
\text { available. }\end{array}$ \\
\hline $\begin{array}{l}\text { An inquiry systcm for trantaction } \\
\text { information is avalable. }\end{array}$ & $\begin{array}{l}\text { Pearson Comclation } \\
\text { Sig. (2-tailed) }\end{array}$ & 1 & $\begin{array}{l}\left..464^{(z)}\right) \\
.000\end{array}$ & $\begin{array}{l}51+(1 ;) \\
.000\end{array}$ \\
\hline Online fligit bookirg is available. & $\begin{array}{l}\text { Pearson Correlation } \\
\text { Sig. (2-tailed) }\end{array}$ & $\begin{array}{l}\left..4644^{* * 7}\right) \\
.000\end{array}$ & 1 & $\begin{array}{l}.606=7) \\
.000\end{array}$ \\
\hline $\begin{array}{l}\text { A wide variety of paynent methods are } \\
\text { availatle. }\end{array}$ & $\begin{array}{l}\text { Pearson Correlation } \\
\text { Sig. (2-tailef) } \\
\mathrm{y}\end{array}$ & $\begin{array}{l}.514^{(* *)} \\
.000 \\
265\end{array}$ & $\begin{array}{l}\left.\left..606\right|^{(*)}\right) \\
.000 \\
265\end{array}$ & 265 \\
\hline
\end{tabular}

\section{F. Customer Satisfaction Correlation Analysis}

As shown in Table.17, the impressions on the aviation company correlation analysis shows evident significance in all items, which implies the possibility of the impressions on the aviation company having an impact on customer satisfaction. As shown in Table.18, the impressions on the staff correlation analysis shows evident significance in all items, which means that impressions on the staff and customers' satisfaction are correlated. It also shows the possibility of impressions on the staff having an impact on customers' satisfaction. As shown in Table.19, the combined correlation analysis of the customer satisfaction sub-dimension shows evident significance in all items, which means that "Impressions on the Aviation Company" and "Impressions on the Staff" are correlated. It also shows the possibility of it having an impact on customer satisfaction.

TABLE XVI. THE COMBINED CORRELATION ANALYSIS OF THE SERVICES QUALITY SUB-DIMENSION

\begin{tabular}{|c|c|c|c|c|c|}
\hline & & $\begin{array}{l}\begin{array}{l}\text { Related } \\
\text { information }\end{array} \\
\end{array}$ & \begin{tabular}{|l|l}
$\begin{array}{l}\text { Flight } \\
\text { attitude }\end{array}$ & attendants' \\
\end{tabular} & $\begin{array}{l}\begin{array}{l}\text { Baggage } \\
\text { delivery }\end{array} \\
\end{array}$ & Booking service \\
\hline Related information & $\begin{array}{l}\text { Pearsoin } \\
\text { Comelation } \\
\text { Sig. (2-tailed) }\end{array}$ & 1 & $\begin{array}{c}555(* *) \\
.000\end{array}$ & $\begin{array}{l}.632\left({ }^{* *}\right) \\
.000\end{array}$ & $\begin{array}{c}.664\left({ }^{* *}\right) \\
.000\end{array}$ \\
\hline $\begin{array}{l}\text { Flight attendants' } \\
\text { attitude }\end{array}$ & $\begin{array}{l}\text { Pearson } \\
\text { Comelation } \\
\text { Sig. (2-tailed) }\end{array}$ & $\begin{array}{c}.555\left(^{(* *)}\right) \\
.000\end{array}$ & 1 & $\begin{array}{c}.596\left({ }^{* *}\right) \\
.000\end{array}$ & $\begin{array}{c}\left..5344^{(4)}\right) \\
.000 \\
\end{array}$ \\
\hline Baggage delivery & $\begin{array}{l}\text { Pearson } \\
\text { Correlation } \\
\text { Sig. (2-ailed) }\end{array}$ & $\begin{array}{l}.632(4) \\
.000\end{array}$ & $\begin{array}{l}.596\left({ }^{\circ 1}\right) \\
.000\end{array}$ & 1 & $\begin{array}{c}.548\left({ }^{(90)}\right) \\
.000\end{array}$ \\
\hline Booking service & $\begin{array}{l}\text { Pearsoin } \\
\text { Conrelation } \\
\text { Sig. (2-tailed) } \\
\text { N }\end{array}$ & $\begin{array}{c}\left..6644^{(*)}\right) \\
.000 \\
265\end{array}$ & $\begin{array}{c}.534\left({ }^{(*)}\right) \\
.000 \\
263\end{array}$ & $\begin{array}{l}.548\left({ }^{* *}\right) \\
.000 \\
265\end{array}$ & 265 \\
\hline
\end{tabular}

TABLE XVII. BRAND IMAGE CORRELATION ANALYSIS OF THE AVIATION COMPANY

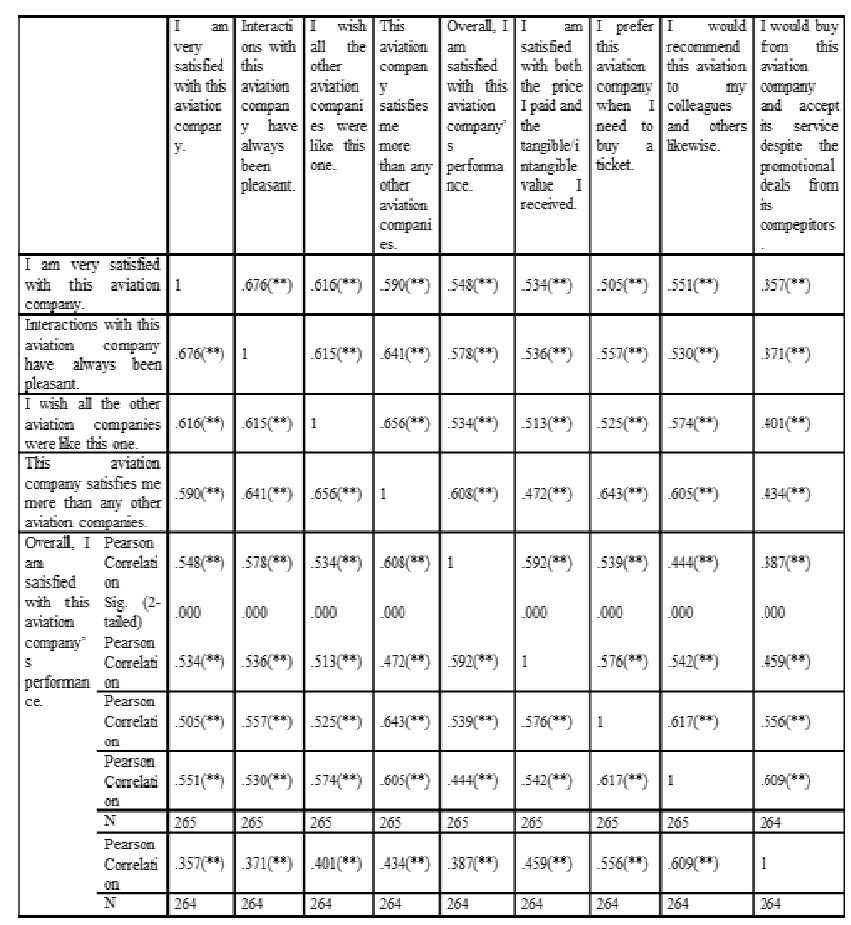

TABLE XVIII. IMPRESSIONS ON THE STAFF CORRELATION ANALYSIS

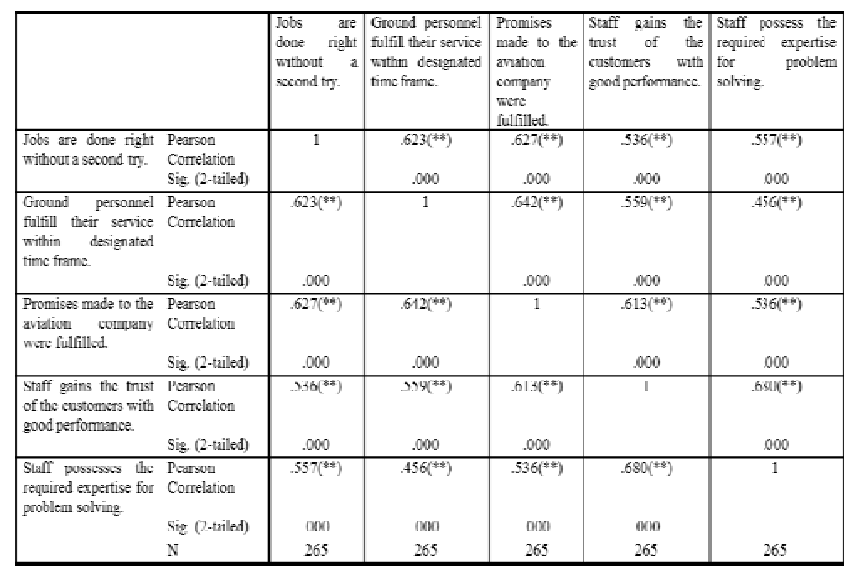

TABLE XIX. CUSTOMER SATISFACTION SUB-DIMENSION CORRELATION ANALYSIS

\begin{tabular}{|c|c|c|c|}
\hline & & $\begin{array}{l}\text { Impressions on } \\
\text { the aviation } \\
\text { company }\end{array}$ & Impressions on the staff \\
\hline Impressions on the aviation company & $\begin{array}{l}\text { Pearson } \\
\text { Contelation } \\
\text { Sig. (2-tailed) }\end{array}$ & 1 & $\begin{array}{c}.730\left({ }^{(*)}\right) \\
.000\end{array}$ \\
\hline Irmpressivils un the stall & $\begin{array}{l}\text { Pearson } \\
\text { Contelation } \\
\text { Sig. (2-tailed) } \\
\text { N }\end{array}$ & $\begin{array}{l}.730\left({ }^{(49}\right) \\
.000 \\
264\end{array}$ & 265 \\
\hline
\end{tabular}




\section{G. One-way ANOVA and Multiple Comparison Analysis}

1)ANOVA of age, marriage, and occupation on each dimension of factor

As shown in Table.20, the ANOVA of age shows significance in "Related Information" and "Booking Service", indicating that individuals in different ranges of age hold different opinions, as people from different generations think and feel differently. The ANOVA of marriage shows significance in "Baggage Delivery", "Booking Service", and "Impressions on the Staff". Individuals of different marriage status hold slightly different opinions on the safety and integrity of the valuables in their baggage, the accessibility of the booking service, and their impressions on the staff. The ANOVA of occupation shows significance in "Related Information", "Flight Attendants' Attitude", "Baggage Delivery", "Booking Service", and "Impressions on the Staff". Individuals of different occupations hold different opinions on flight attendants' attitude, related information, booking services, and their impressions on the staff, as each individual experiences the service provided by China Airline with the perspective of his/her own career.

TABLE XX. THE ANOVA OF AGE OCCUPATION ON EACH DIMENSION OF FACTOR

\begin{tabular}{|c|c|c|c|c|c|c|}
\hline Dimension of Factor & \multicolumn{2}{|c|}{ Age } & \multicolumn{2}{|c|}{ Marriage } & \multicolumn{2}{|c|}{ Occupation } \\
\hline & $F$ & Sig. & $F$ & $8 i s$ & $\bar{F}$ & Sig \\
\hline Enlenprix Operalions & .666 & .650 & 1.122 & 290 & 1.098 & .365 \\
\hline Enterprise Scale & .939 & .456 & .704 & .402 & 1.033 & .409 \\
\hline Related Information & 3.250 & $.00 ?$ & 1.607 & .206 & 3.885 & .000 \\
\hline Attendants' Attitude & 1.638 & .150 & 3.257 & .072 & 2.174 & .037 \\
\hline Dageage Delivery & 1.764 & .121 & 4.533 & .034 & 3.655 & .001 \\
\hline Dooking Service & 4.142 & .001 & 7.545 & .006 & 2.110 & .043 \\
\hline $\begin{array}{l}\text { Impressions on the } \\
\text { Aviation Company }\end{array}$ & 1.279 & .273 & 3.556 & .060 & 1.884 & .072 \\
\hline Impressions on the Staff & 1.786 & .116 & 4.322 & .039 & 2.091 & .045 \\
\hline
\end{tabular}

TABLE XXI. THE MULTIPLE COMPARISON ANALYSIS OF AGE AND SERVICE QUALITY

\begin{tabular}{|c|l|c|c|c|}
\hline $\begin{array}{c}\text { Dimension of Evaluating } \\
\text { Factor }\end{array}$ & \multicolumn{1}{|c|}{ Age } & F & T & Multiple comparison \\
\hline Related Information & $\begin{array}{l}(1) 20 \text { and under(2)21-30 } \\
(3) 31-40(4) 41-50 \\
(5) 51-60(6) 61 \text { and above }\end{array}$ & 3.250 & .007* & $\begin{array}{l}(2)>(6) \\
(3)>(6)\end{array}$ \\
\hline Booking Service & $\begin{array}{l}(1) 20 \text { and under(2)21-30 } \\
(3) 31-40(4) 41-50\end{array}$ & 4.142 & .001* & $\begin{array}{l}(2)>(6) \\
(5) 51-60(6) 61 \text { and above }\end{array}$ \\
\hline
\end{tabular}

2)The multiple comparison analysis of age and service quality

As shown in Table.21, the result of the multiple comparison analysis shows statistical significance between age and two factors of service quality, "Related Information", and "Booking Service". Regarding the related information, individuals in the age of $21 \sim 30$ and $31 \sim 40$ give better results than those in the age of 51 60. Regarding the booking service, individuals in the age of $21 \sim 30$ and 31 40 give better results than those in the age of 51 60. The mean is 11.698 and 11.698 respectively. There shows no statistical significance between the factors of age, attendants' attitude, and baggage delivery, therefore, no comparison is needed. As shown in Table.22, the result of the multiple comparison anal result than military, public, and teaching personnel. The mean is 11.601. There shows no statistical significance between occupation and related information, flight attendants' attitude, and booking service, thus no comparison is needed.

TABLE XXII. THE MULTIPLE COMPARISON ANALYSIS OF OCCUPATION QUALITY

\begin{tabular}{|c|c|c|c|c|}
\hline Dimensirueterafuating Fotor & Oscuptive & $\mathbf{F}$ & I & Muting enapris or \\
\hline Bagogage Delivery & 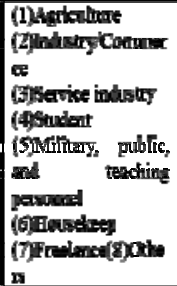 & 3.655 & $.001^{\circ}$ & (3) $)(5)$ \\
\hline
\end{tabular}

\section{CONCLUSION}

1. Customers in the age of $21 \sim 30$ should be the primary targets in the aviation company's marketing strategy, as they take up to $50.9 \%$ of the aviation company's total customers.

2. The subjects of this questionnaire consist mostly of individuals in the service industry, hence the high proportion of individuals with college and university educations and the overall result of above than average educations.

3. The main customer base is those in the service industry who take part in incentive travels. objective perspective, China Airline should reinforce its strategic promotions on customers in the service industry.

4. From the objective perspective, China Airline should reinforce its strategic promotions on customers in the service industry

\section{REFERENCES}

[1] Howard, J. A. \& J. N. Sheth (1969). The Theory of Buyer Behavior New York Wiley, 27-P28

[2] Kotler, P., \& Armstrong, G, (1996), Principles of marketing (7th ed.), New Jersey: Prentice-Hall International, Inc.

[3] Maslow, A. H. (1968). Toward a psychology of being. New York: Van Nostrand Reinhold.

[4] Keller, KL.(1993).Conceptualizing, measuring, anaging customer-based brand. Journal of Marketing, 57(1). 1-23.

[5] Aaker, D. A. (1991). Managing brand equity: Ccapitalizing on the value of a brand name. New York: The Free Press.

[6] Keller, K. L. (1993). Conceptualizing, measuring, managing customer-based brand equity. Journal of Marketing, 57(1), pp. 1-22.

[7] Kotler, P. (1999), - Marketing Management - An Asian Perspective. $\|$, Singapore: Prentice Hall.

[8] Gronroos, Christian. (1990) Service Management and Marketing, Lexington Books, pp.28.

[9] Ajzen, I. \& Driver, B.L., (1992), Application of the Theory of Planned Behavior to Leisure Choice, Journal of Leisure Research, 24 ( 3 ), 207-224. 